\title{
The aquatic glacial relict fauna of Norway - an update of distribution and conservation status
}

\author{
Ingvar Spikkeland', Björn Kinsten', Gösta Kjellberg, Jens Petter Nilssen and Risto Väinölä
}

Spikkeland I, Kinsten B, Kjellberg G, Nilssen JP, Väinölä R. 2016. The aquatic glacial relict fauna of Norway - an update of distribution and conservation status. Fauna norvegica 36: 51-65.

The aquatic "glacial relict" fauna in Norway comprises a group of predominantly cold-water animals, mainly crustaceans, which immigrated during or immediately after the deglaciation when some of the territory was still inundated by water. Their distribution is mainly confined to lakes in the SE corner of the country, east of the Glomma River in the counties of Akershus, Østfold and Hedmark. We review the history and current status of the knowledge on this assemblage and of two further similarly distributed copepod species, adding new observations from the last decades, and notes on taxonomical changes and conservation status. By now records of original populations of these taxa have been made in 42 Norwegian lakes. Seven different species are known from Lake Store Le/Foxen on the Swedish border, whereas six species inhabit lakes Femsjøen, Øymarksjøen and Rødenessjøen, and five are found in Aspern, Aremarksjøen and in the largest Norwegian lake, Mjøsa. From half of the localities only one of the species is known. The most common species are Mysis relicta (s.str.), Pallaseopsis quadrispinosa and Limnocalanus macrurus. Some populations may have become extirpated recently due to eutrophication, acidification or increased fish predation. Apart from the main SE Norwegian distribution, some lakes of Jæren, SW Norway, also harbour relict crustaceans, which is puzzling. The region is disjunct from any current fresh- or brackish-water sources, whereas following the early deglaciation it bordered the large, dry landmass of Doggerland, now the submerged bottom of the North Sea. While the Jæren Mysis population indeed is found to represent a different, plausibly more salt-tolerant species than that in SE Norway, the recent discovery of the freshwater amphipod Pallaseopsis quadrispinosa from the same lake upholds the zoogeographical enigma.

doi: 10.5324/fn.v36i0.1994. Received: 2016-05-03. Accepted: 2016-08-05. Published online: 2016-12-20. ISSN: 1502-4873 (printed), 1891-5396 (electronic).

Keywords: glacial relicts, biogeography, Mysis, Pallaseopsis, Monoporeia

1. Østfold Museum Foundation, Dep. Haldenvassdragets Kanalmuseum, P.O. Box 64, N-1870 Ørje, Norway.

2. Fagerövägen 57B, SE-791 53 Falun, Sverige.

3. Müller-Sars Society, P.O. Box 5831, N-0308 Oslo, Norway

4. Natural History Museum, P.O. Box 1172 Blindern, University of Oslo, N-0318 Oslo, Norway, present address: Müller-Sars Society, Dept. Free Basic Research, P.O. Box 5831, N-0308 Oslo, Norway.

5. Finnish Museum of Natural History, P.O. Box 17, FI-00014 University of Helsinki, Finland.

Corresponding author: Ingvar Spikkeland

E-mail:ingspi@ostfoldmuseene.no 


\section{INTRODUCTION}

The "glacial relicts" is a designation for a group of aquatic animals, mainly crustaceans, whose distributions in the Nordic countries and North America are characteristically restricted to lakes in regions that immediately after the ice age were covered by water and are thus situated below the highest postglacial shoreline of a larger water body, either a marine one or a continental lake such as the early phases of the Baltic Sea (e.g. Ekman 1922, Segerstråle 1957). They typically inhabit cold and low-light environments, and are usually encountered in deep-water strata in larger lakes. The exact composition or delimitation of this biogeographical element is still a matter of discussion, but in Norway, species in five genera of crustaceans and one fish species have generally been considered (Table 1; Figure 1): the calanoid copepod Limnocalanus macrurus, mysid shrimps of the Mysis relicta species group, the three amphipods Monoporeia affinis (= Pontoporeia affinis), Pallaseopsis quadrispinosa (= Pallasea quadrispinosa) and Gammaracanthus lacustris, and the fish fourhorn sculpin Myoxocephalus quadricornis (Økland 1983, Økland \& Økland 1999, cf. Segerstråle 1957). Most of these taxa also inhabit the brackish waters of the Baltic Sea. Another Baltic crustacean, the large isopod Saduria entomon, is also found as a relict in a few lakes but has not been recorded in Norway; the nearest site is the Swedish Lake Vänern. There are additional similarly distributed species whose inclusion in the relict element has been discussed; of them the two copepods Eurytemora lacustris and Cyclops lacustris will also be considered here (see further in the Material and Methods section).

The concept of the taxa being relicts has a complex history (e.g. Ekman 1922, Segerstråle 1957, 1962, 1982, Holmquist 1966). Initially it referred to a scenario where arctic marine species would have become isolated from the sea in emerging lakes post-glacially, and evolved into new forms, as glacial marine relicts. Later, the species have rather been thought to have immigrated from continental glacial lakes of the Late Pleistocene, and descended from marine ancestors much earlier (e.g. Segerstråle 1962, Holmquist 1966), whereby the attribute marine has been dropped. The long history of the species in fresh waters has also been supported by more recent molecular systematic studies and biogeographical surveys of the component taxa (e.g. Väinölä et al. 1994, 2001, Dooh et al. 2006, Audzijonyte \& Väinölä 2006).

Nevertheless, the designation "relict" has conventionally been used in most regions where these taxa occur (Finland, Sweden, Canada: see e.g. Ricker 1959, Segerstråle 1982, Kinsten 2012), although Holmquist $(1962,1966)$ was quite critical of this denomination (also see Dadswell 1974). In Norway, the concept "relikt" in a biogeographical context generally denotes small remnant populations of an earlier, broader and continuous geographical distribution. Since there is no evidence that these animals would initially have had more continuous distributions across Norwegian lakes (see Økland
1983: 15-16, Økland \& Økland 1999: 66), it does not seem justified to consider them as glacial relicts in the sense of that definition. Instead, the use of the term "glacial immigrants", suggested earlier e.g. by Dadswell (1974), was proposed by Økland \& Økland (1999). That term, however, seems not less problematic (at any rate, a large share of other fauna also immigrated early during the deglaciation). Here we shall keep to using the terms "relict" and "glacial relict", not because of semantics, but as representing convenient and established labels for the distinct zoogeographical assemblage, used through the history of investigations (e.g. Ekman 1922, Segerstråle 1962, Väinölä \& Rockas 1990, Kinsten 2012).

Several of the glacial relict genera display wide, nearly circumpolar distributions over the Northern Hemisphere, and the freshwater populations are primarily found in the southernmost parts of the regions covered by the last continental ice sheet, in the boreal zone (Ekman 1922, 1940, Sømme 1936, Ricker 1959, Dadswell 1974, Carter et al. 1980, Bousfield 1989, Väinölä \& Rockas 1990). The European distribution of the assemblage comprises parts of the British Isles, Norway, Denmark, Germany, Sweden, Poland, Finland, Estonia, Latvia, Lithuania, Belarus and Northwest Russia. However, the core region is in Sweden, Finland, Karelia (Russia) and the Baltic Sea. In Norway the relicts are mainly restricted to large and deep lakes below the postglacial marine limit in the southeastern part of the country. When the relative water levels in the early Baltic (Østersjøen) were high about 10000 years ago during the so-called Yoldia-stage and immediately thereafter, it drained into the Skagerrak across central Sweden and through the large lakes Vättern and Vänern. This connection essentially controlled the distribution of the taxa both in Central Sweden and south-eastern Norway (e.g. Kinsten 2012). They mainly inhabit the deeper strata of the lakes, and most of them cannot move upstream, which have greatly limited their further geographical dispersal (Segerstråle 1962, 1982, Dadswell 1974, Väinölä \& Rockas 1990). There is, however, an interesting deviation to the main pattern in outpost populations at three sites in Jæren, SW Norway, where two of the sites are situated above the marine limit (Mathisen 1953, Spikkeland et al. 2012b). Moreover, Mysis is known from a single northern lake on the Norwegian-Finnish border, which is clearly zoogeographically unrelated to the main "relict" range (e.g. Väinölä et al. 1994).

The concepts of the systematic diversity in the relict genera have also changed with time, with consequences for the views about their history. In particular, European vs. North American relicts have been divided into separate species, or even into separate genera (Bousfield 1989, Audzijonyte \& Väinölä 2005). But even within Europe the conventional Mysis relicta has been split into three closely related freshwater species, apart from an additional North American one (Väinölä et al. 1994, Audzijonyte \& Väinölä 2005). This is important for the understanding of the history of Norwegian populations. In south-eastern Norway, the only identified Mysis taxon is Mysis relicta, whereas the southwestern population of 
Lake Stokkalandsvatnet uniquely belongs to Mysis salemaai (Audzijonyte \& Väinölä 2005). Another circum-arctic sibling species Mysis segerstralei was identified in the northern Lake Polmakvatnet, partly in Finnmark (Väinölä et al. 1994, Audzijonyte \& Väinölä 2005), but also from a brackish water-site in the same county (Kålås et al. 2010). These latter observations remove the northern Mysis populations from the context of conventional freshwater boreal relict zoogeography, and rather indicate they represent true post-glacial isolates of arctic marine taxa (Väinölä 1993, Audzijonyte \& Väinölä 2006). Notably, similar systematic subdivisions among North European populations of other relict taxa (i.e. Myoxocephalus, Pallaseopsis, Monoporeia, Gammaracanthus) have not been found in molecular studies (Kontula \& Väinölä 2003, R. Väinölä, unpubl. data).

More lately the geographical ranges have also been shaped
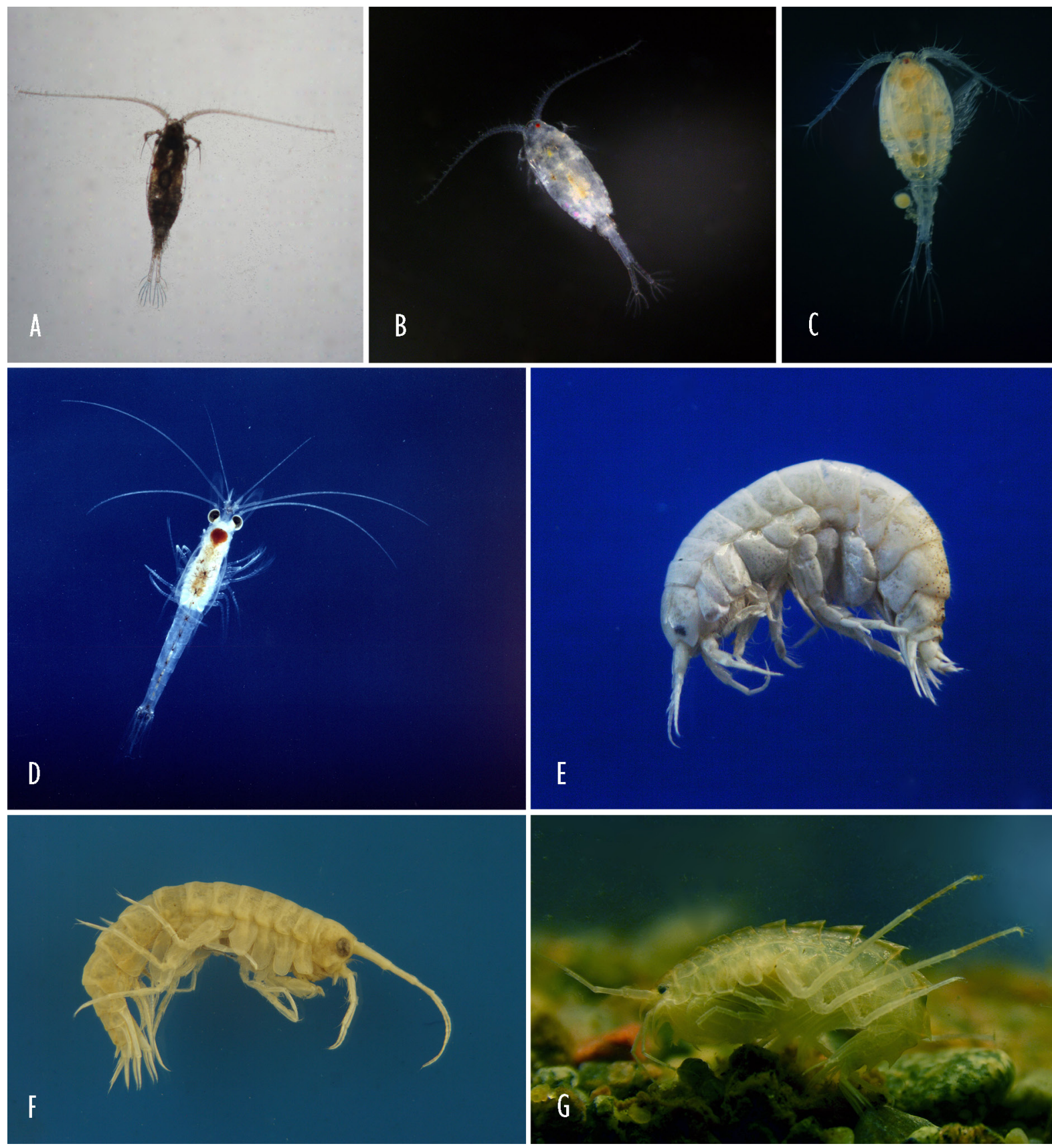

Figure I. Glacial relict crustaceans in Norway. A: Limnocalanus macruris B: Eurytemora lacustris C: Cyclops lacustris D: Mysis relicta E: Monoporeia affinis F: Pallaseopsis quadrispinosa G: Gammaracanthus lacustris. The two species Mysis relicta and Mysis salemaai are almost identical in appearance. The similarly distributed copepods Eurytemora lacustris and Cyclops lacustris are included (see discussion in text). (Photos: Mysis relicta: Arild Hagen, the other photos Ingvar Spikkeland). 
by man. In Norway the two taxa Mysis relicta and Pallaseopsis quadrispinosa were introduced into some 10 hydropower reservoirs in the Trøndelag area (Central Norway) in the 1960s and 1970s, and have later spread to several lakes downstream. As a result of these introductions, Mysis is now known from 16 Norwegian lakes, and in some of these lakes Pallaseopsis is also present (Gösta Kjellberg pers. comm.). Mysis relicta was perhaps also introduced to Lake Rognestøylsvatn in Møre og Romsdal (see Næsje \& Sandlund 2006). The rationale of these introductions was to improve the feeding base of fish such as brown trout. It soon proved, however, that Mysis constituted an intense food competitor for pelagic fish: it consumed large amounts of zooplankton, which led to strong decrease in biomass of the Arctic char, which largely depends on the same food source (Langeland 1981, Økland 1983, Baste 1988, Økland \& Økland 1995, Næsje \& Sandlund 2006, also cf. Ellis et al. 2011).

The regional distributions of the "glacial relict" populations have been summarised and updated at intervals e.g. in Sweden (Ekman 1940, Holmquist 1966, Kinsten 2012) and Finland (Segerstråle 1956, Väinölä \& Rockas 1990). The last comprehensive review form Norway was by Mathisen (1953), after which the knowledge has increased significantly. For instance, the fourhorn sculpin Myoxocephalus quadricornis, a circumpolar marine fish taxon long also known from Swedish and Finnish lakes, was first recorded in Norway in 1978 in Lake Mjøsa (Sandlund 1979). In 1979 it was found on the Swedish side of the boundary lake Store Le/Foxen and in 1998 also from the Norwegian part (Henrikson et al. 1980, Andersen et al. 1998). The focus of the current paper is in updating and commenting on the distributional data of the Norwegian glacial relicts from the published and unpublished sources, including results of our recent surveys.

\section{MATERIAL AND METHODS}

The knowledge of the Norwegian distribution of the glacial relicts, and the history of that knowledge, were summarised using data (i) from published records, (ii) from new field surveys and observations during the past few decades, and (iii) from the unpublished archives of G.O. Sars, primarily from the late 19th century.

New data came mainly from our own field surveys, where four methods have been utilised: (1) a small benthic beam trawl usually applied at the greatest depths $(30 \times 50 \mathrm{~cm}$ aperture, later on a trawl with $30 \times 100 \mathrm{~cm}$ aperture, mesh size $1 \mathrm{~mm}$ ); (2) a zooplankton net (mesh size $100 \mu \mathrm{m}, \mathrm{d}=20 \mathrm{~cm}$ ) towed vertically from the bottom (at greatest depth) to the surface; (3) the zooplankton net towed horizontally attached to the bottom trawl; (4) a Van Veen Grab Sampler for bottom sediment samples.

The posthumous archival material of the carcinologist G.O. Sars (1837-1927) was surveyed. Thousands of tubes and slides are stored in the G.O. Sars Collection at the Natural History Museum, University of Oslo. Additionally, several thousand scientific illustrations and further reference material (e.g. diaries, notebooks etc., altogether about 300 items) are stored in the National Library, Oslo. This material was utilised to gather information concerning distribution and the initial chronology of collection of the relict taxa (see Appendix). The unpublished illustrations, diaries and notebooks contain rich sources of information.

Besides the traditional relict species assemblage, we also report records of the two copepod species Eurytemora lacustris and Cyclops lacustris. Based on broad distributional correlations in freshwaters of other regions, E. lacustris (Figure 1B) has indeed also previously been suggested as one of the relict taxa (Särkkä et al. 1990, Kasprzak et al. 2005, Maier et al. 2011). Nevertheless, since it is occasionally found above the postglacial marine limit, it is not considered a true glacial relict species in Sweden (Kinsten 2012). Due to the biogeographical association, we, however, include it in the Norwegian relict species count. $C$. lacustris in turn is zoogeographically a typical so-called Baltic species, with a distribution related to the Ancylus stage of the post-glacial Baltic Sea development (Ekman 1922). As the species has earlier been reported from the upper water layers, it seemed that it is not a genuine glacial relict (Sars 1918). Yet in Lake Mjøsa the species preferred colder waters and was during the mid-summer stratification period distributed in colder water masses in hypolimnion (Huitfeldt-Kaas \& Føyn 1946), which is in accord with our own observations from lakes in the Halden River watershed. While the glacial relict concept is somewhat vague anyway, we also report on the new information on C. lacustris in this account, along with the similarly distributed E. lacustris (cf. Kasprzak et al. 2005, Maier et al. 2011). Further taxa that have been related to or mentioned together with the glacial relicts, but are not listed here, include the fish Osmerus eperlanus (smelt), present in all the large lakes in the Halden River watershed as well as in many other lakes with the relict crustaceans (cf. Ekman 1922, Thienemann 1950, Kinsten 2012), and the calanoid copepod Heterocope borealis (Ekman 1922).

\section{RESULTS AND DISCUSSION}

\section{Progress in knowledge of glacial relict distribution}

An updated list of the aquatic glacial relict taxa in Norway is presented in Table 1; the inclusion of the copepods Eurytemora lacustris and Cyclops lacustris, conventionally not part of the relict element, is explained above.

All Norwegian lakes where native populations of relict species are recorded are presented in Table 2, together with some important geographic and morphometric characteristics. The lakes are grouped according to which catchment area they belong to, starting in the southeast and ending up in Jæren, SW Norway. 
Table I. The aquatic "glacial relicts" and zoogeographically or systematically associated taxa of Norway, as dealt with in this paper. Status: Red List category (Oug et al. 2015): NT: Near Threatened, VU: Vulnerable.

\begin{tabular}{lll}
\hline Scientific name & Norwegian name & Taxonomic group \\
\hline Limnocalanus macrurus G.O. Sars, 1863 & Flammekreps & Crustacea: Copepoda \\
*Eurytemora lacustris (Poppe, 1887) & & Crustacea: Copepoda \\
*Cyclops lacustris G.O. Sars, 1863 & & Crustacea: Copepoda \\
Mysis relicta Lovén, 1862 (s.str.) & Pungreke (mysis) & Crustacea: Mysida \\
Mysis salemaai Audzijonyte \& Väinölä, 2005 & Pungreke (mysis) & Crustacea: Mysida \\
**Mysis segerstralei Audzijonyte \& Väinölä, 2005 & Pungreke (mysis) & Crustacea: Mysida \\
Gammaracanthus lacustris G.O. Sars, 1867 & Trollistidskreps & Crustacea: Amphipoda \\
Pallaseopsis quadrispinosa (G.O.Sars, 1867) & Firetornet istidskreps & Crustacea: Amphipoda \\
Monoporeia affinis (Lindström, 1855) & Flatbent istidskreps & Crustacea: Amphipoda \\
Myoxocephalus quadricornis (Linnaeus, 1758) & Hornulke & Pisces: Scorpaeniformes \\
\hline * Similarly distributed species not regularly included in the relict element & & \\
** A sub-arctic sibling species not following the conventional boreal "glacial relict” distribution pattern & \\
\hline
\end{tabular}

The gradual progress in the knowledge of the crustacean distributions is detailed in the Appendix table, which gives the chronology of the first records and the first recorders of each taxon in each lake. These data are summarised in Tables 3 and 4 , which present the full list of localities of natural occurrence known to date and a less detailed account of the progress of exploration, separating the earliest and the most recent (unpublished) finds.

The glacial relict community was initially described from Sweden by Lovén $(1862,1863)$ and the first to mention it from Norway was Georg Ossian Sars (1863a), one of the major Norwegian aquatic scientists throughout all times. In his early work on the taxonomy, systematics and distribution of Norwegian freshwater crustaceans (Sars 1867, see also the complete publication list in Christiansen 1993), he described them in detail. He also coined the scientific species names for three of them (see Table 1). Regarding the chronology (Appendix), it is noted that the first records sometimes were long before the first publication. For instance, regarding Lake Hurdalssjøen, Sømme (1936) wrote: "As far as I know, Mysis relicta has never been dealt with from this locality. From my friend cand. real. G. Rollefsen, who found the species in Hurdalssjøen in 1925, I know that Sars was aware of its occurrence in the Hurdalsjø". When the exact first record is not known, the first published record is indicated.

Before World War II there was great scientific and socioeconomic interest in these animals by fisheries scientists and authorities, since they were large-sized and potentially important as fish food. Several new geographical records were made (Sømme 1936), and by 1940 they were known from 19 lakes and one river locality. In 1942-1943 the fisheries scientist O.A. Mathisen carried out a distributional survey on the commission from fisheries authorities. His summary of glacial relict distribution in the 1950s listed 24 lakes and 2 rivers
(Mathisen 1953). His additions involved Mysis from three lakes, including Stokkalandsvatnet of Jæren, and Monoporeia and Pallaseopsis from four lakes each.

Following this intense sampling period, no systematic effort to broaden the information was taken for a long time, whereas individual crustacean finds in various lakes of the Hedmark, Østfold, Vestfold and Buskerud counties were made and sometimes published (Aass 1969, Hardeng 1982, Vøllestad 1983, Spikkeland 1997, Bækken et al. 1999, Malmestrand 2002, Walseng \& Hesthagen 2012, Schartau et al. 2013), but often remained undocumented (unpublished records of E. Snekvik, I. Spikkeland, H. Ørjasæter, G. Hardeng, J.P. Nilssen, A. Linløkken; see details in the Appendix).

In 1996, the Canal Museum of the Halden River watershed (Haldensvassdragets Kanalmuseum, now a department of Østfold Museum Foundation), took renewed interest in the distribution of glacial relicts in the Halden River watershed, and produced many additional records (Spikkeland et al. 2012a). The southwestern Jæren region (Rogaland) was also re-investigated (Spikkeland et al. 2012b), but since the colonisation of this region must have followed a different pattern, the findings are discussed separately in the final section of this article.

\section{Updated distribution maps}

In total, 42 lakes in Norway are so far known to have original populations of glacial relicts. The natural distribution of each species is presented in Figure 2. The most common of these species are Limnocalanus macrurus, Mysis relicta and Pallaseopsis quadrispinosa, recorded in 22, 21 and 20 lakes respectively (Table 3). The amphipod Gammaracanthus lacustris and the copepod Eurytemora lacustris in turn are recorded from 9 and 8 lakes, respectively. The rarest taxa are Mysis salemaai and the fish Myoxocephalus quadricornis. Records of the copepod Cyclops lacustris in Table 2 are not 
Table 2. Geographical and morphometric characteristics of Norwegian lakes with naturally occurring populations of glacial relicts. Geographic coordinates are given for lake outlet. Watershed code: AS: Askerelva, BL: Blindevannsbekken, BY: Byälven, DK: Dalslands Kanal/Upperudvassdraget, DR: Drammensvassdraget. EN: Enningdalsvassdraget, GL: Glomma, HA: Haldenvassdraget, LJ: Ljanselva, MO: Morsa, OR: Orrevassdraget. SO: Sognsvannsbekken, ST: Storåna. County code: A: Akershus, B: Buskerud, H: Hedmark, O: Oppland, R: Rogaland, V: Vestfold, Ø: Østfold.

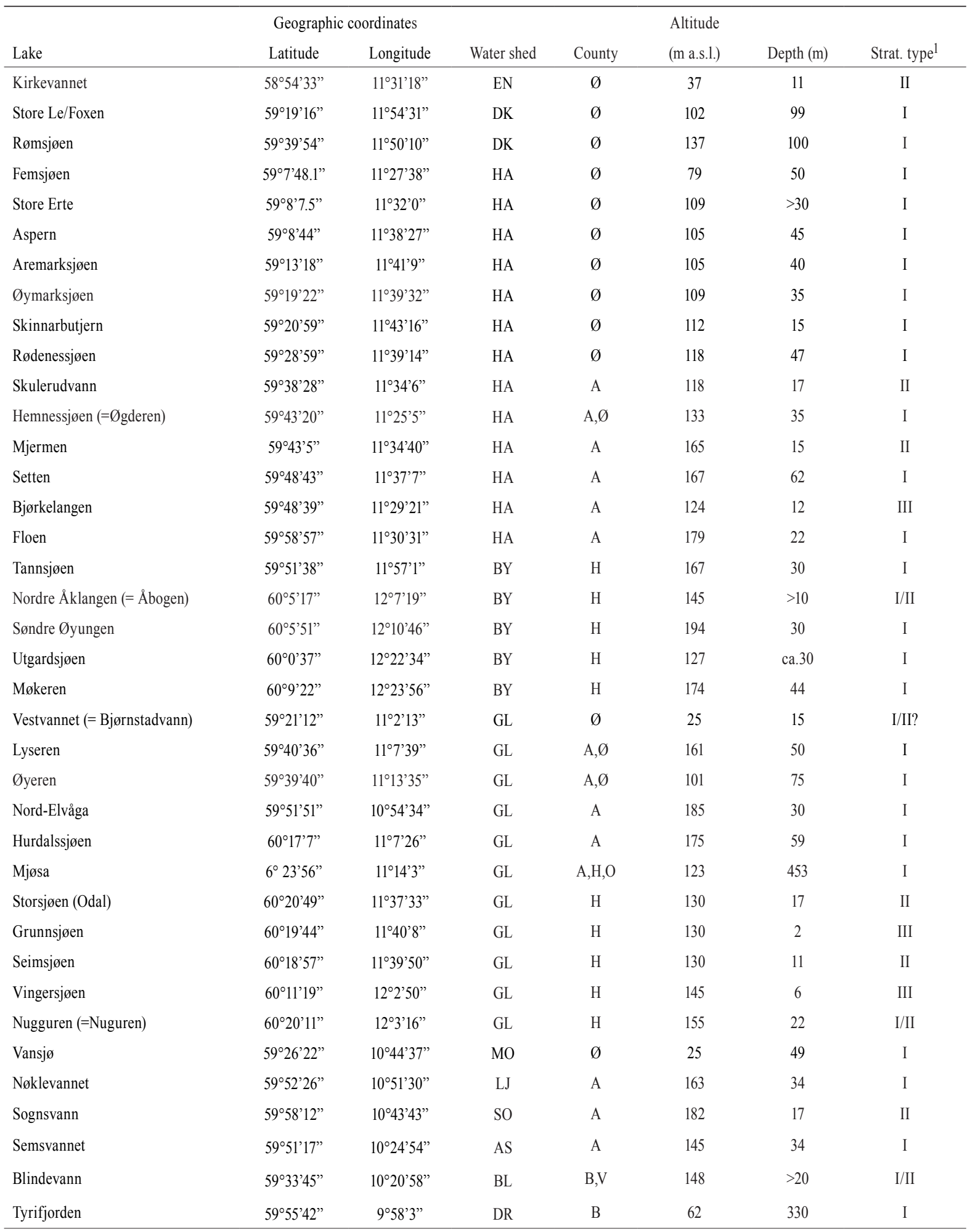


Table 2. Continued.

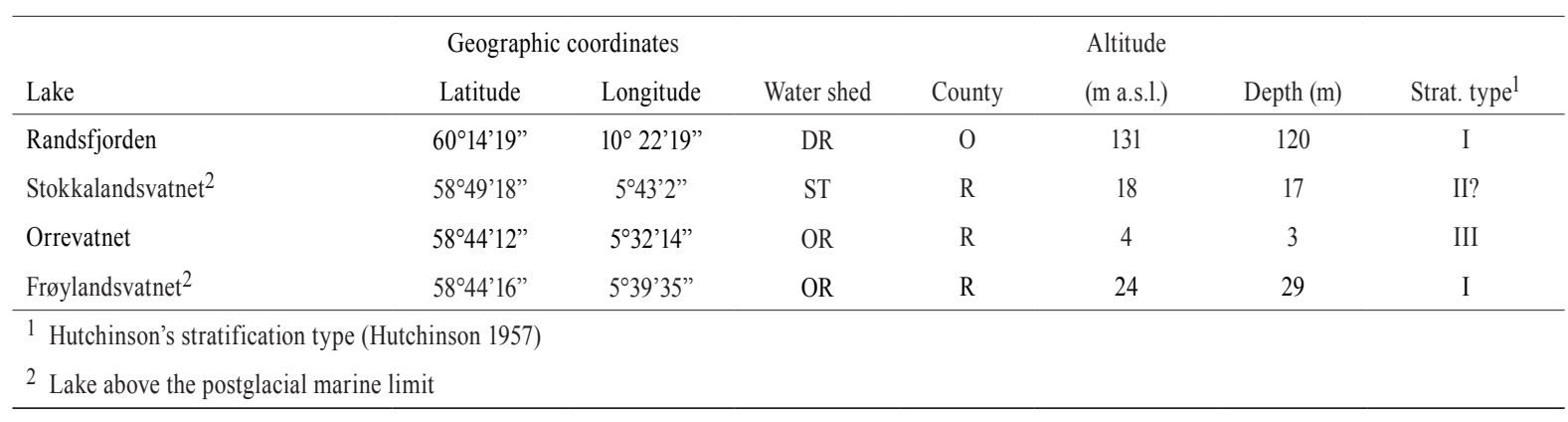

included in the count of relict species in a given lake. The information on introduced populations outside the natural range has been summarised in Næsje \& Sandlund (2006).

The Halden River watershed and the Lake Store Le/Foxen in the county of Østfold constitute the core distribution of the relicts in Norway. Store Le/Foxen is the only lake that has altogether seven species, in addition to Cyclops lacustris, which is also present in the lake. The Halden River watershed has six species (the fourhorn sculpin Myoxocephalus quadricornis not recorded). All six are known from the three lakes Femsjøen, Øymarksjøen and Rødenessjøen, but other sites might turn up in more thorough surveys. Cyclops lacustris is known from nine lakes in this watershed (Table 2). Lake Mjøsa, the largest lake in Norway, harbours five species, missing records of Eurytemora lacustris, Monoporeia affinis and Mysis salemaai. Cyclops lacustris is the dominant cyclopoid copepod in this lake. From the remaining localities, one to four of the taxa are known.

The crustaceans have also been recorded in some rivers, especially as regards Pallaseopsis quadrispinosa (Table 4). This is evidently related to the occurrence of the species in upstream lakes. Our studies in the Ørjeelva River have confirmed that even other taxa enter the river during the cold seasons, and especially Mysis relicta may occur in large numbers after the late-autumn and winter mating period, when dead and dying animals are drifting down the river. The exact distribution in the rivers, however, is not known in detail, and in Figure 2 only occurrences in lakes are indicated.

\section{Conservation status}

In previous Norwegian Red List assessments (Kålås et al. 2006, 2010), most relict taxa were placed in the categories NT (near threatened) or DD (data deficient), and Eurytemora lacustris and Cyclops lacustris in EN (endangered) and VU (vulnerable), respectively. The central reason was the low number of occurrences; only Mysis relicta and Pallaseopsis quadrispinosa were considered safe. In the most recent 2015 edition, most species were downgraded to LC (least concern) and thus removed from the red list (Oug et al. 2015; see Table 1). This revision was principally based on the increase in the knowledge of the distribution since 2010, i.e. on the new records detailed in the present paper, especially those from the Halden
River watershed. Also no evidence of range fragmentation or threats for species survival were observed.

The only species that remain on the list are the two recently separated Mysis taxa, i.e. M. salemaai, now moved from the DD to the VU category, and M. segerstralei (NT). Both species are widespread on a broader geographical scale, but their Norwegian occurrences are unique and deserve some further comment. Mysis salemaai is abundant in the single lake Stokkalandsvatnet, but for Mysis this is a small lake (ca. 50 ha) and situated in a cultural landscape and therefore subject to some risk, e.g. through eutrophication and introduction of new fish species. The previous DD status was justified by the insufficient information on potential distribution elsewhere in Norway (Kålås et al. 2010). Nevertheless, from the recent surveys of the Jæren area (Spikkeland et al. 2012) and from distributional correlations and concepts of the history of the two Mysis species in the bordering regions of Sweden (Väinölä et al. 1994; Oug et al. 2015) it seems quite unlikely that M. salemaai would actually live elsewhere in Norway.

The evaluation of the northern Mysis segerstralei as NT was entirely based on a single record from a Finnmark estuary (Porsangen), with a notion that other estuarine populations might occur but the range is necessarily fragmented (Oug et al. 2015). That dismissed the freshwater occurrence of the species in Lake Polmakvatnet. While strictly speaking $M$. segerstralei was so far only collected from the Finnish side of that trans-boundary lake, this should not divert the attention. The Polmakvatnet population is the single known freshwater occurrence of this species both in (continental) Norway, in Finland, and in the entire European Union, and therefore also of wider conservation interest, representing a unique biogeographical element in continental waters of the region (discussed in Väinölä 1993). The lake, ca. $10 \mathrm{~km}$ long and 30 $\mathrm{m}$ deep, is situated ca. $15 \mathrm{~m}$ above the sea level. It was isolated from Tanafjorden of the Barents Sea post-glacially relatively late, ca. 5000 years ago. (Indeed, that history most closely corresponds with the original idea of "marine glacial relicts" presented in connection with the earliest freshwater finds, while the more southerly relicts, dealt with here, are now thought to have their ancestry in continental ice-marginal lakes.) Väinölä et al. (1994) and earlier Holmquist (1959) surveyed a set of similar lakes in Northern Norway, with no additional finds of 
Table 3. Lakes in Norway with records of naturally occurring populations of the studied taxa. Occurrence: $\square$ : Occurrences published $1863-$ 1953, o: Occurrences published 1954-2000, •: Occurrences published after 2000, +: New localities reported here

\begin{tabular}{|c|c|c|c|c|c|c|c|c|c|c|}
\hline Lake & 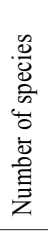 & 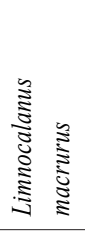 & 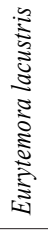 & 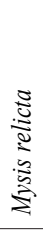 & 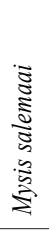 & 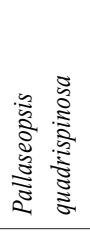 & 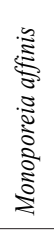 & 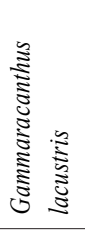 & 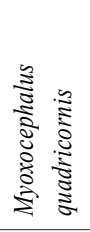 & 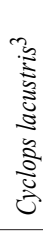 \\
\hline Store Le/Foxen & 7 & $\square$ & o & $\square$ & & $\square$ & $\square$ & $\square$ & o & $\bullet$ \\
\hline Femsjøen & 6 & $\square$ & $\square$ & $\square$ & & $\square$ & $\bullet$ & $\bullet$ & & $\bullet$ \\
\hline Øymarksjøen & 6 & o & o & 0 & & ० & $\bullet$ & $\bullet$ & & $\bullet$ \\
\hline Rødenessjøen & 6 & ० & $\bullet$ & $\square$ & & $\square$ & $\bullet$ & $\square$ & & $\bullet$ \\
\hline Aspern & 5 & 0 & $\bullet$ & $\circ$ & & $\bullet$ & & $\bullet$ & & $\bullet$ \\
\hline Aremarksjøen & 5 & o & $\bullet$ & 0 & & $\bullet$ & & $\bullet$ & & $\bullet$ \\
\hline Setten & 5 & $\bullet$ & & $\bullet$ & & $\bullet$ & + & $\bullet$ & & \\
\hline Mjøsa & 5 & $\square$ & & $\square$ & & $\square$ & & $\square$ & o & $\square$ \\
\hline Skulerudvann & 4 & $\bullet$ & $\bullet$ & $\bullet$ & & $\bullet$ & & & & $\bullet$ \\
\hline Hemnessjøen (=Øgderen) & 4 & $\bullet$ & & $\square$ & & o & $\circ$ & & & + \\
\hline Øyeren & 4 & $\square$ & & $\square$ & & $\square$ & & $\square$ & & + \\
\hline Hurdalssjøen & 3 & $\square$ & & $\square$ & & $\square$ & & & & \\
\hline Storsjøen (Odal) & 3 & $\square$ & & & & $\square^{1}$ & $\square^{1}$ & & & \\
\hline Utgardsjøen & 3 & $\square$ & & & & $\square$ & $\square$ & & & \\
\hline Rømsjøen & 2 & & & $\bullet$ & & & $\bullet$ & & & $\bullet$ \\
\hline Nord-Elvåga & 2 & & & $\square$ & & & $\square$ & & & \\
\hline Mjermen & 2 & $\bullet$ & & $\bullet$ & & & & & & \\
\hline Grunnsjøen & 2 & & & & & $\square^{1}$ & $\square^{1}$ & & & \\
\hline Seimsjøen & 2 & & & & & $\square^{1}$ & $\square^{1}$ & & & \\
\hline Vingersjøen & 2 & & & & & $\square$ & $\square$ & & & \\
\hline Stokkalandsvatnet ${ }^{2}$ & 2 & & & & $\square$ & $\bullet$ & & & & \\
\hline Skinnarbutjern & 1 & & & & & $\bullet$ & & & & \\
\hline Floen & 1 & $\square^{1}$ & & & & & & & & + \\
\hline Store Erte & 1 & $\square^{1}$ & & & & & & & & \\
\hline Kirkevannet & 1 & & $\bullet$ & & & & & & & \\
\hline Vestvannet (=Bjørnstadvann) & 1 & $\square^{1}$ & & & & & & & & \\
\hline Vansjø & 1 & & & $\circ$ & & & & & & \\
\hline Lyseren & 1 & & & o & & & & & & \\
\hline Nøklevannet & 1 & & & & & & $\square$ & & & \\
\hline Bjørkelangen & 1 & & & o & & & & & & + \\
\hline Sognsvann & 1 & & & & & & $\square$ & & & \\
\hline Semsvannet & 1 & & & & & & $\square$ & & & \\
\hline Søndre Øyungen & 1 & & & o & & & & & & \\
\hline Nordre Åklangen (=Åbogen) & 1 & & & & & $\square^{1}$ & & & & \\
\hline Møkeren & 1 & $\square$ & & & & & & & & \\
\hline Nugguren (=Nuguren) & 1 & & & $\square$ & & & & & & \\
\hline Tannsjøen & 1 & & & $\bullet$ & & & & & & \\
\hline Tyrifjorden & 1 & $\square$ & & & & & & & & $\square^{1}$ \\
\hline
\end{tabular}




\begin{tabular}{|c|c|c|c|c|c|c|c|c|c|c|}
\hline Lake & 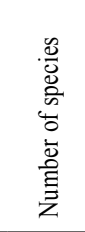 & 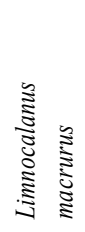 & 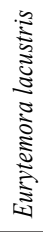 & 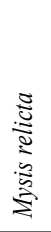 & 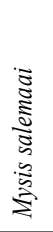 & 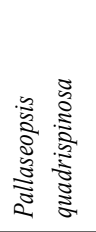 & 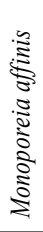 & 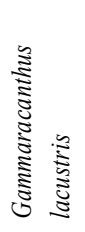 & 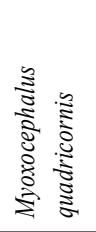 & 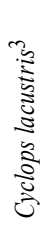 \\
\hline Randsfjorden & 1 & $\square$ & & & & & & & & \\
\hline Blindevann & 1 & $\bullet$ & & & & & & & & \\
\hline Orrevatnet & 1 & & & & & & $\square^{1}$ & & & \\
\hline Frøylandsvatnet ${ }^{2}$ & 1 & & & & & & $\square$ & & & \\
\hline Number of lakes known 2015 & Tot. 42 & 22 & 8 & 21 & 1 & 20 & 18 & 9 & 2 & 14 \\
\hline \multicolumn{11}{|l|}{${ }^{1}$ Probably extirpated } \\
\hline \multicolumn{11}{|c|}{${ }^{2}$ Lake above the postglacial marine limit } \\
\hline${ }^{3}$ Cyclops lacustris is not incl & ecies & & & & & & & & & \\
\hline
\end{tabular}

Mysis. However, the species is known from further east, from the White Sea and lakes on the Kola Peninsula, as well as Svalbard (Audzijonyte \& Väinölä 2005, 2006).

\section{Trends and prospects}

Even if the species in south-eastern Norway would not seem to be threatened at a regional or national level, we have noted some negative trends on more local scales. At several localities, populations of relict crustaceans seem to have disappeared during recent years. Thus Limnocalanus macrurus has probably extirpated from Lake Vestvannet (Nilssen 2009), Monoporeia affinis from Lake Orrevatnet (Väinölä \& Rockas 1990, Spikkeland et al. 2012b) and Lake Storsjøen (G. Kjellberg pers. obs.), and Pallaseopsis quadrispinosa from the Storsjø watershed in the Odal Region, Hedmark (Storsjøen, Seimsjøen, Grunnsjøen and Oppstadåa) and Lake Nordre Åklangen (G. Kjellberg pers. obs.). Also, sampling in Lake Floen in 2012 and 2015 (I. Spikkeland pers. obs.) and Lake Store Erte in 1994, 1995, 1996 and 2012 (Walseng \& Karlsen 1997, I. Spikkeland pers. obs.) suggest that Limnocalanus macrurus has disappeared from these two lakes, probably due to acidification (this concerns especially the most acidified Lake Store Erte during the most acidic period). Also, the copepod Cyclops lacustris, which was registered by G.O. Sars in Lake Tyrifjorden, may have disappeared from this site (Langeland 1974). Both Gammaracanthus lacustris and Monoporeia affinis, although recently being recorded from several new localities in the Halden River watershed, are usually detected in very low numbers. In spite of intensive sampling in October 2015, M. affinis was not redetected in Lake Hemnessjøen and $G$. lacustris not in Lake Øyeren. As for Lake Hemnessjøen and other polluted lakes in the Halden River watershed, it seems that lack of oxygen in hypolimnion in stagnation periods threatens the populations of especially these two relict species.
On the other hand, the total distribution of the relict taxa is still probably incompletely known, and more comprehensive studies, using several field methods simultaneously, might reveal more occurrences especially in SE Norway and even in the Jæren area. In particular, we may expect more finds of Mysis relicta, which Kinsten (2012) has shown to be present even in very small-sized lakes in Sweden, as long as their deep parts remain rich in oxygen. In addition to recording the incidence of the species, more quantitative studies of abundance and of autecology such as life histories of the different species should be designed (cf. Mathisen 1953, Kjellberg et al. 1991).

Since the glacial relicts mainly inhabit deep and cold water, they are generally vulnerable to low oxygen conditions following eutrophication processes (e.g. Nilssen 2009). Climate change is also expected to cause increasing input of organic matter and decrease of oxygen levels in deep waters. Sometimes the relicts may endure considerable humic contents, and thus low oxygen conditions in the hypolimnion (Väinölä \& Rockas 1990), but they appear extremely vulnerable towards acidification (Kinsten 2012).

The goal now in Norway, at the distributional margins of the relict assemblage, should be to ensure favourable ecological conditions where the species occur, such that the local populations can survive and thrive, and even repopulate sites where they have become rare or extirpated. This especially concerns the very vulnerable, interesting and geographically isolated populations in the Jæren region, more closely dealt with below.

\section{Jæren, SW Norway - an outpost in the Norwegian glacial relict distribution}

The Jæren area makes a special case, being separated from the core relict distribution in SE Norway by about 300 $\mathrm{km}$, and requiring an another hypothesis for its immigration 
history. Two species were previously known from this region, from three lakes. The last survey in 2012 found them surviving in two of the three: Mysis salemaai was redetected in Lake Stokkalandsvatnet and Monoporeia affinis in Lake Frøylandsvatnet, whereas M. affinis was not caught from Lake Orrevatnet in spite of intensive search (Spikkeland et al. 2012b, see also Väinölä and Rockas 1990). In further search of the region, no relict species were found from Lake Bråsteinvatnet, due upstream from Lake Stokkalandsvatnet, and situated above the postglacial marine limit. However, three individuals of Pallaseopsis quadrispinosa, not previously known from the region, were collected from Lake Stokkalandsvatnet (Spikkeland et al. 2012b). The record was particularly unexpected in view of the hypotheses of the relicts' invasion to the Jæren region. It has been assumed that they were spread with the Norwegian Current system following the brackish-water currents from the Baltic region at the end of the last glacial period (Mathisen 1953, Segerstråle 1957, Väinölä et al. 1994). P. quadrispinosa has been regarded an almost purely freshwater taxon, unlike the relatively euryhaline Monoporeia affinis and Mysis salemaai, although it is recorded in the Baltic at ca. $0,5 \%$ salinity. Dispersal along the Norwegian Current system may therefore

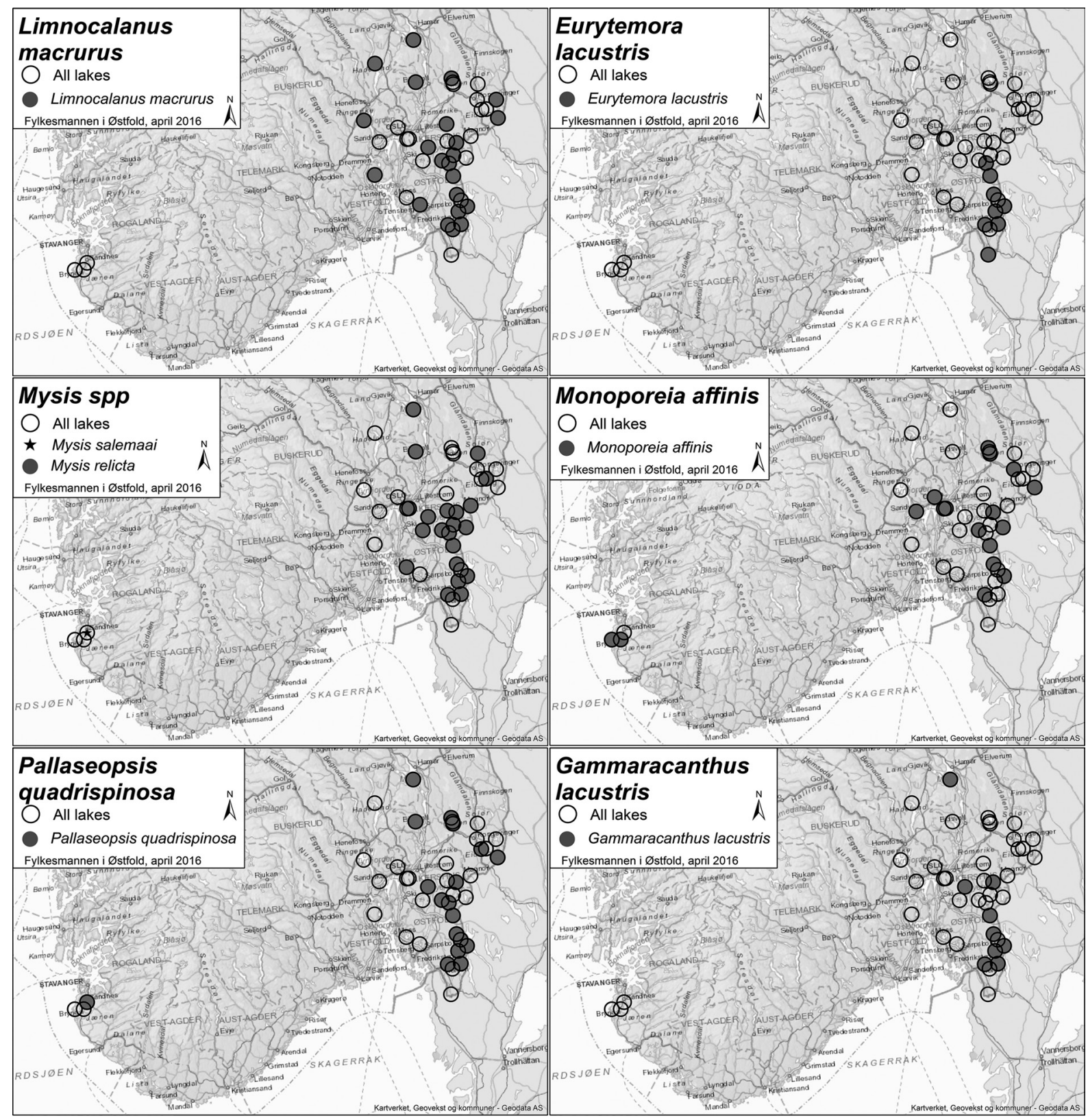

Figure 2. The currently known natural distributions of the glacial relict crustaceans in Norway. Map source: Kartverket, Geovekst og kommuner - Geodata AS. 
Table 4. Rivers in Norway with naturally occurring populations of glacial relicts. A: Akershus, H: Hedmark, O: Oppland, Ø: Østfold. Occurrence: ○: Localities published before 2000 •: Localities published after 2000 .

River
$\begin{aligned} & \text { Orjeelva } \\ & \text { (downstream lake Rødenessjøen) }\end{aligned}$
$\begin{aligned} & \text { Glomma } \\ & \text { (downstream Kongsvinger) }\end{aligned}$
$\begin{aligned} & \text { Andelva } \\ & \text { (downstream lake Hurdalssjøen) }\end{aligned}$
$\begin{aligned} & \text { Vorma } \\ & \text { (downstreams lake Mjøsa) }\end{aligned}$
$\begin{aligned} & \text { Oppstadåa } \\ & \text { (downstream lake Storsjøen) }{ }^{1}\end{aligned}$
$\begin{aligned} & \text { Gudbrandsdalslågen } \\ & \text { (lower part) }\end{aligned}$

be a possible explanation. However, the glacial relicts are not recorded from the southernmost part of Norway, along the 300 $\mathrm{km}$ coastline between the main distribution area in the east and the Jæren region. This indicate that their dispersal history in Jæren area may be different. Moreover, the occurrence seems even more puzzling since Lake Stokkalandsvatnet is situated above the postglacial marine limit. A spread of these crustaceans by man is also very unlikely (Spikkeland et al. 2012b). It should be noted, however, that the exact marine limit position in this region is still under debate (Nilssen et al. 2013).

The occurrence of the glacial relicts in Jæren has recently been related to the very special geomorphological development of the region during and after the last glacial period (Nilssen et al. 2013). The Quaternary evolution of the Jæren region and the adjacent waters that cover the former and now submerged Doggerland is now known in much greater detail than earlier. This large piece of dry land that for several thousand years stretched across the current North Sea, from Britain to the present coasts of the Netherlands, Germany and Denmark and in the northeast bordered at the Norwegian Trench, might have facilitated the dispersal of Pallaseopsis quadrispinosa to the Jæren region (Nilssen et al. 2013). Concerning a possible dispersal via Doggerland, it is noted that $P$. quadrispinosa is also known from several sites in Denmark (Jutland and
Sjælland; e.g. Wesenberg-Lund et al. 1917, Sand-Jensen 1995), which could be relicts from an earlier continuous distribution in the Doggerland. Apart from Pallaseopsis, other species of the relict assemblage, i.e. Limnocalanus macrurus, Monoporeia affinis and Mysis salemaai, could also have spread via fresh and brackish waters on the Doggerland, considering their present distributions in the British Isles (Pennington 1959), Denmark and the Jæren region.

An assessment of the mitochondrial DNA of one Stokkalandsvatn Pallaseopsis specimen, however, showed that it represents the same lineage that is also present in Lake Mjøsa and elsewhere in Fennoscandia, and unlikely to be of different refugial origin (R. Väinölä, unpubl. data). On the other hand, assessing the relationships of the Stokkalandsvatn Mysis salemaai, using both mitochondrial and nuclear marker genes, pointed out the independent history of the population (e.g. in terms of genetic bottlenecks) but did not definitely resolve its relative affinities with either Swedish, Danish or British populations of the same species (Väinölä et al. 1994, Audzijonyte \& Väinölä 2006).

\section{ACKNOWLEDGEMENTS}

Many persons have helped with the collection of material and data in this study, and both Charlotte Holmquist $(\dagger)$ and Sven G. Segerstråle $(\dagger)$ have provided information at early phases of our studies. The Canal Museum of the Halden River watershed (Haldensvassdragets Kanalmuseum, now a department of Østfold Museum Foundation, Norway) has supplied boat and other field equipment, and both the Østfold Museum Foundation, the Müller-Sars Society and the Chief of Fishery Management, Governor of Østfold, have given economic support. Aase Richter, Dep. of Environmental Conservation, Governor of Østfold, produced the distribution maps, Arild Hagen supplied photos, Geir Hardeng relevant literature, Odd Terje Sandlund gave information on Mysis in Lake Lyseren and Gøran Brattstrøm has checked the English. We thank them all.

\section{REFERENCES}

Aass P. 1969. Mysis relicta i Vansjø, Østfold. Fauna (Oslo) 22: 161. Andersen JG, Andersen O, Halvorsrud AK, Lindblad F, Lund SV, Spikkeland I. 1998. Hornulke - ny fiskeart for Østfold. Natur i Østfold 17(1-2): 5-6.

Audzijonyte A, Väinölä R. 2005. Diversity and distributions of circumpolar fresh- and brackish-water Mysis (Crustacea: Mysida): descriptions of M. relicta Lovén, 1862, M. salemaai n. sp., M. segerstralei n. sp. and M. diluviana n. sp., based on molecular and morphological characters. Hydrobiologia 544: 89-141. doi: 10.1007/s10750-004-8337-7

Audzijonyte A, Väinölä R. 2006. Phylogeographic analyses of a circumarctic coastal and a boreal lacustrine mysid crustacean, and evidence of fast postglacial mtDNA rates. Molecular 
Ecology 15: 3287-330. doi: 10.1111/j.1365-294X.2006.02998.x

Bækken T, Kjellberg G, Linløkken A. 1999. Overvåking av bunndyr i grensekryssende vassdrag i Østlandsområdet i forbindelse med vassdragskalking. DN-notat 1999-2. $55 \mathrm{pp}$.

Baste IA. 1988. Utsetting av Mysis relicta som et fiskeforsterkingstiltak - Bakgrunn om forvaltningsmessig status. Fiskesymposiet februar 1988. Vassdragsregulantenes forening. $276 \mathrm{pp}$.

Bousfield EL. 1989. Revised morphological relationships within the amphipod genera Pontoporeia and Gammaracanthus and the "glacial relict" significance of their postglacial distributions. Canadian Journal of Fisheries and Aquatic Sciences 46 (10): 1714-1725. doi: 10.1139/f89-217

Brøgger CW. 1900-1901. Om de senglaciale og postglaciale nivåforandringer i Kristianafeltet. Molluskfaunaen. Norges Geologiske Undersøkelser No. 31: 1-731.

Carter JCH, Dadswell MJ, Roff JC, Sprules WG. 1980. Distribution and zoogeography of planktonic crustaceans and dipterans in glaciated eastern North America. Canadian Journal of Zoology 58: 1355-1387. doi: 10.1139/z80-188

Christiansen ME. 1993. Georg Ossian Sars (1837-1927), the great carcinologist of Norway. Crustacean Issues 8: 143-164.

Dadswell MJ. 1974. Distribution, ecology, and postglacial dispersal of certain crustaceans and fishes in eastern North America. National Museum of Natural Sciences Publication of Theses in Zoology 11: 1-110.

Dooh RT, Adamowicz SJ, Hebert PDN. 2006. Comparative phylogeography of two North American 'glacial relict' crustaceans. Molecular Ecology 15: 4459-4475. doi: 10.1111/j.1365-294X.2006.03095.x

Ekman S. 1922. Djurvärldens utbredningshistoria på skandinaviska halvön. Bonniers. $614 \mathrm{pp}$.

Ekman S. 1940. Die Schwedische Verbreitung der glazialmarinen Relikte. Verhandlungen des Internationalen Verein Limnologie 9: 37-58.

Ellis BK, Stanford JA, Goodman D, Stafford CP, Gustafson DL, Beauchamp DA, Chess DW, Craft JA, Deleray MA, Hansen BS. 2011. Long-term effects of a trophic cascade in a large lake ecosystem. Proceedings of the National Academy of Sciences of the United States of America 108 (3): 1070-1075. doi: 10.1073/ pnas. 1013006108

Hardeng G. 1982. Haldenvassdraget og Store Le. Østfoldnatur nr. 15. $148 \mathrm{pp}$.

Henrikson L, Nyman HG, Oscarson HG. 1980. Den glasialmarina relikten hornsimpa Oncocottus quadricornis (L.) påträffad i sjön Stora Le i Dalsland. Fauna och Flora 75: 269-270.

Holmquist C. 1959. Problems on marine-glacial relicts on account of investigations on the genus Mysis. Lund. $270 \mathrm{pp}$.

Holmquist C. 1962. The relict concept - Is it a merely zoogeographical conception? Oikos 13: 262-292.

Holmquist C. 1966. Die sogennanten marin-glazialen Relikte nach neueren Gesichtspunkten. Archiv für Hydrobiologie 62: 285-326.

Huitfeldt-Kaas H, Føyn B. 1946. The plankton in Mjøsa. Nytt Magasin for Naturvidenskapene 85: 161-222.

Hutchinson GE. 1957. A treatise of limnology. Volume I. Geography, physics, and chemistry. John Wiley \& Sons, NY. 1015 pp.

Kålås JA, Viken Å, Bakken T (eds.). 2006. Norsk Rødliste 2006.
Artsdatabanken, Norway. 415 pp.

Kålås JA, Viken A, Henriksen S, Skjelseth S (eds.). 2010. Norsk rødliste for arter 2010. The 2010 Norwegian Red List for Species. Artsdatabanken, Norway. $480 \mathrm{pp}$.

Kasprzak P, Reese C, Koschel R, Schulz M, Hambaryan L, Mathes J. 2005. Habitat characteristics of Eurytemora lacustris (POPPE, 1887) (Copepoda, Calanoida): The role of lake depth, temperature, oxygen concentration and light intensity. Internationale Revue der gesamten Hydrobiologie und Hydrographie 90: 292-309. doi: 10.1002/iroh.200410769

Kinsten B. 2012. De glacialrelikta kräftdjurens utbredning i Sverige. Havs- och vattenmyndigheten. Publ. (1). 284 pp.

Kjellberg G, Hessen D, Nilssen JP. 1991. Life history, growth and production of Mysis relicta in the large, fjord-type Lake Mjøsa, Norway. Freshwater Biology 26: 165-173.

Kontula T, Väinölä R. 2003. Relationships of Palearctic and Nearctic 'glacial relict' Myoxocephalus sculpins from mitochondrial DNA data. Molecular Ecology 12 (11): 3179-3184. doi: 10.1046/j.1365-294X.2003.01963.x

Langeland A. 1974. Long-term changes in the plankton of Lake Tyrifjord, Norway. Norwegian Journal of Zoology 22: 207-219.

Langeland A. 1981. Decreased zooplankton density in two Norwegian lakes caused by predation of recently introduced Mysis relicta. Verhandlungen des Internationalen Verein Limnologie 21: 926-937.

Lovén S. 1862. Om några i Vättern och Vänern funna Crustaceer. Öfversigt af Kongliga Vetenskaps-Akademiens Förhandlingar 1861(6): 285-314.

Lovén S. 1863. Till frågan om Ishafsfaunans fordna utsträckning öfver en del af Nordens fastland. Öfversigt af Kongliga Vetenskaps-Akademiens Förhandlingar 1862(8): 463-468.

Løkke ER. 1964. Lysern. En innsjø med uregelmessig omriss i det sør-østnorske grunnfjellsområdet. Unpublished Cand. real. thesis in geography. University of Oslo. $65 \mathrm{pp}$.

Maier G, Speth B, Arp W, Bahnwart M, Kasprzak P. 2011. New records of the rare glacial relict Eurytemora lacustris (Poppe, 1887) (Copepoda; Calanoida) in atypical lake habitats in northern Germany. Journal of Limnology 70: 145-148. doi: 10.3274/JL11-70-1-17

Malmestrand H. 2002. Glacialrelikta kräftdjur i Värmlands län 2001. Länstyrelsen i Värmlands län. Publ. (4). 30 pp.

Mathisen OA. 1953. Some investigations of the relict crustaceans in Norway with special reference to Pontoporeia affinis Lindström and Pallasea quadrispinosa G.O. Sars. Nytt Magasin for Zoologi 1: 49-86.

Næsje F, Sandlund OT. 2006. Pungreke Mysis spp. Artsdatabanken Faktaark nr. 30. http://www2.artsdatabanken.no/faktaark/ Faktaark30.pdf. Accessed 2015-12-18.

Nilssen JP. 2009. Glomma og dens nedslagsfelt i Østfold: limnologisk naturtilstand og økologisk stress fra 1880-tallet til i dag belyst med mikrokrepsdyr. Müller-Sars Selskapet. Rapport nr. 9 - 2009. 53 pp.

Nilssen JP, Kjellberg G, Spikkeland I. 2013. Jæren og kystområdet i lavereliggende deler av Rogaland - en særegen biogeografisk og $ø$ kologisk region for ferskvannsorganismer i Norge. Stavanger Museum Årbok 2012: 118-143.

Nybelin O. 1929. Några nya svenska fyndlokaler för maringlaciala relikter. Fauna och Flora 24: 20-29.

Økland J. 1983. Ferskvannets verden 3. Regional økologi og 
miljøproblemer. Universitetsforlaget. 189 pp.

Økland J, Økland KA. 1995. Vann og Vassdrag 1. Ressurser og problemer. Vett \& Viten. 357 pp.

Økland J, Økland KA. 1999. Vann og Vassdrag 4. Dyr og planter: Innvandring og geografisk fordeling. Vett \& Viten. 200 pp.

Oug E, Brattegard T, Walseng B, Djursvoll P. 2015 Krepsdyr (Crustacea). In: Henriksen S, Hilmo O (eds.). Norsk rødliste for arter 2015. Artsdatabanken http://www.artsdatabanken.no/ Rodliste/Artsgruppene/Krepsdyr. Accessed 2015-12-18.

Pennington W. 1959. Relict Fauna of Ennerdale Water; a Problem of Distribution. Nature 184: 1421-1423.

Ricker KE. 1959. The origin of two glacial relict crustaceans in North America, as related to Pleistocene glaciations. Canadian Journal of Zoology 37: 871-893.

Sandlund OT. 1979. Hornulke i Mjøsa - ny fiskart for Norge. Fauna (Oslo) 32: 1-3.

Sand-Jensen K. 1995. Furesøen gennem 100 år. Naturens Verden 1995-5: 176-187.

Särkkä J, Meriläinen JJ, Hynynen J. 1990. The distribution of relict crustaceans in Finland: new observations and some problems and ideas concerning relicts. Annales Zoologici Fennici 27: 221-225.

Sars GO. 1863a. Beretning om en i Sommeren 1862 foretagen zoologisk Reise i Christianias og Trondhjems Stifter. Nyt Magazin for Naturvidenskaberne 12: 193-252.

Sars GO. 1863b. Stud. med. G. O. Sars gav en af talrige Afbildninger ledsaget Oversigt af de indenlandske Ferskvandscopepoder. Forhandlinger i Videnskabs-selskabet i Christiania 1862: 212262.

Sars GO. 1867. Histoire naturelle des Crustacées d'eux douce de Norvège. I. Les Malacostracés. Chr. Johnsen, Chistiania.

Sars GO. 1895. An account of the Crustacea of Norway. Vol. I Amphipoda. Christiania and Copenhagen 1895. 493 pp.

Sars GO. 1903. An account of the Crustacea of Norway. IV Copepoda, Calanoida. Bergen. $171 \mathrm{pp}$.

Sars GO. 1918. An account of the Crustacea of Norway VI Copepoda, Cyclopoida, Bergen. 325 pp.

Schartau AK, Skjelbred B, Edvardsen H, Fløystad L, Jensen TC, Mjelde M, Petrin Z, Saksgård R, Sandlund OT. 2013. Utprøving av system for basisovervåking $\mathrm{i}$ henhold til vannforskriften. Resultater for utvalgte innsjøer 2012. Miljøovervåking i vann 2013-4. 105 pp.

Segerstråle SG. 1956. The distribution of glacial relicts in Finland and adjacent Russian areas. Societas Scientiarum Fennica, Commentationes Biologi 15(18): 1-35.

Segerstråle SG. 1957. On immigration of the glacial relicts of Northern Europe, with remarks on their prehistory. Soc. Sci. Fennica, Comment. Biol. 16(16): 1117.

Segerstråle SG. 1962. The immigration and prehistory of the glacial relicts of Eurasia and North America; a survey and discussion of modern views. Internationale Revue der gesamten Hydrobiologie und Hydrographie 47: 1-25.

Segerstråle SG. 1982. The immigration of glacial relicts into Northern Europe in the light of recent geological research. Fennia 160: 303-312.

Sømme S. 1936. Contribution to the biology of Norwegian fish food animals. Some small collections of Amphipoda and Mysis relicta from Norwegian Lakes. Avhandlinger Norske Videnskaps-Akademi Matematisk-Naturvidenskapelig Klasse
1936 (9): 1-11.

Spikkeland I. 1997. Biologisk mangfold i Haldenvassdraget, med hovedvekt på ferskvannssnegl og krepsdyr. Vann 32(4): 423-431.

Spikkeland I, Kasbo R. Kjellberg G, Nilssen JP, Opsahl R, Vaaler JP. 2012a. Istidsinnvandrere ("istidsrelikter") i ferskvann - nye observasjoner og oppdatering av utbredelsen i Norge. Fauna (Oslo) 65 (3): 82-96

Spikkeland I, Kinsten B, Kjellberg G. 2012b. Istidskreps på Jæren. Undersøkelse av innsjøene Bråsteinvatnet, Stokkalandsvatnet, Frøylandsvatnet og Orrevatnet september 2012. Østfoldmuseenes skriftserie, Avdeling Haldenvassdragets Kanalmuseum, Ørje, Rapport 2/2012. 12 pp.

Thieneman A. 1950. Verbreitungsgeschichte der Süsswassertierwelt Europas. Versuch einer historischen Tiergeographie der europäischen Binnengewässer. Binnengewässer 18: 1-809.

Väinölä R.1993. Zoogeography of "glacial relict" crustaceans in northern Fennoscandia - a molecular systematic approach. Oulanka Reports 12: 109-113.

Väinölä R, Rockas H. 1990. New distributional data on "glacial relict" crustaceans. Annales Zoologici Fennici 27: 215-220.

Väinölä R, Riddoch BJ, Ward RD, Jones RI. 1994. Genetic zoogeography of the Mysis relicta species group (Crustacea: Mysidacea) in northern Europe and North America. Canadian Journal of Fisheries and Aquatic Sciences 51: 1490-1505. doi: 10.1139/f94-149

Väinölä R, Vainio JK, Palo JU. 2001. Phylogeography of "glacial relict" Gammaracanthus (Crustacea, Amphipoda) from boreal lakes and the Caspian and White seas. Canadian Journal of Fisheries and Aquatic Sciences 58: 2247-2257. doi: 10.1139/ cjfas-58-11-2247

Vøllestad LA. 1983. Nye funn av istidsimmigrantene Pontoporeia affinis, Pallasea quadrispinosa og Mysis relicta i Norge. Fauna (Oslo) 36: 129-131.

Walseng B, Karlsen LR. 1997. Reetablering av forsuringsfølsomme invertebrater etter kalking av ferskvann i Østfold. NINA Oppdragsmelding 490: 1-32.

Walseng B, Hesthagen T. 2012. Enningdalsvassdraget, en ferskvannsbiologisk dokumentasjon. Del 1 - Krepsdyr. NINA Rapport 827. 54 pp.

Wesenberg-Lund C, Sand MJ, Boye-Petersen J, Steenberg CM. 1917. Furesøstudier - en bathymetrisk botanisk zoologisk undersøgelse af Mølleaaens Søer. Det Kongelige Danske Videnskabers Selskabs Skrifter, Naturvidenskabelig og Matemaisk Afdeling, 8. Række, III: 1-208.

Editorial responsibility: Anne Helene Solberg Tandberg.

This article is open-access and distributed under the terms of the Creative Commons Attribution 4.0 International license. This permits all non-commercial use, distribution, and reproduction in any medium, provided the original work is properly cited. (http://creativecommons.org/licenses/by/4.0/). 
Appendix. Chronology of the dates of first records of individual species dealt with in this paper. Superscripts refer to the footnote, which gives names of the observers and the publication reference (if any). County codes A: Akershus, B: Buskerud, H: Hedmark, O: Oppland, R: Rogaland. V: Vestfold, Ø: Østfold.

\begin{tabular}{|c|c|c|c|c|c|c|c|c|}
\hline Lake & County & 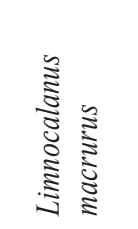 & 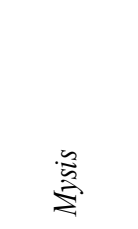 & 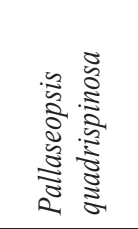 & 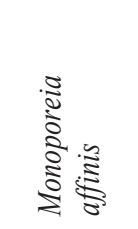 & 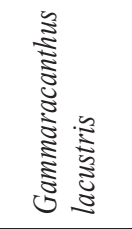 & 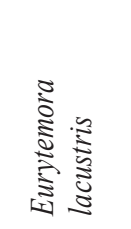 & 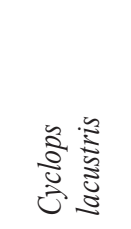 \\
\hline Aremarksjøen & $\varnothing$ & $1981^{\mathrm{NH}}$ & $1981^{\mathrm{NH}}$ & $2011^{S V}$ & & $2011 \mathrm{SV}$ & $2012^{\mathrm{IS} 2}$ & $2012^{\mathrm{IS} 2}$ \\
\hline Aspern & $\varnothing$ & $1981^{\mathrm{NH}}$ & $1981^{\mathrm{NH}}$ & $2000^{\mathrm{SE}}$ & & $2008^{\mathrm{KS}}$ & $2011^{\mathrm{IS} 2}$ & $2002 / 3^{J N}$ \\
\hline Bjørkelangen & A & & $1983^{\mathrm{LV}}$ & & & & & $2008^{\mathrm{IS}}$ \\
\hline Blindevann & $\mathrm{B}, \mathrm{V}$ & $2012^{\mathrm{TJ}}$ & & & & & & \\
\hline Femsjøen & $\varnothing$ & $1880 \mathrm{~s}{ }^{\mathrm{GS} 2}$ & $1880 \mathrm{~s}{ }^{\mathrm{GS} 3}$ & $1880 \mathrm{~s}^{\mathrm{GS} 5}$ & $2013^{S V}$ & $2013^{S V}$ & $1880 \mathrm{~s}^{\mathrm{GS} 2}$ & $2011^{\mathrm{IS} 2}$ \\
\hline Floen & A & ? GS? & & & & & & $2015^{\mathrm{IS}}$ \\
\hline Frøylandsvatnet & $\mathrm{R}$ & & & & $1922^{\mathrm{SS} 1}$ & & & \\
\hline Grunnsjøen & $\mathrm{H}$ & & & $1942 / 3 \mathrm{OM}$ & $1942 / 3 \mathrm{OM}$ & & & \\
\hline Hemnessjøen (=Øgderen) & $\mathrm{A}, \varnothing$ & $2008^{\mathrm{IS} 2}$ & $1935^{\mathrm{SS}}$ & $1983^{\mathrm{LV}}$ & $1979^{I V}$ & & & $2015^{\mathrm{IS}}$ \\
\hline Hurdalssjøen & A & $1880 \mathrm{~s}$ GS0 & $1880 \mathrm{~s}$ GS4 & $? 1880 \mathrm{~s}$ GS5 & & & & \\
\hline Kirkevannet & $\varnothing$ & & & & & & $2004^{\mathrm{WH}}$ & \\
\hline Lyseren & $\mathrm{A}, \varnothing$ & & $1960^{\mathrm{ES}}$ & & & & & \\
\hline Mjermen & A & $2005^{\mathrm{IS} 2}$ & $2005^{\mathrm{KS}}$ & & & & & \\
\hline Mjøsa & $\mathrm{A}, \mathrm{H}, \mathrm{O}$ & $1862^{\mathrm{GS} 1}$ & $1862^{\mathrm{GS} 1}$ & $1862^{\mathrm{GS} 1}$ & & $1880 \mathrm{~s}{ }^{\mathrm{GS} 6}$ & & $1862^{\mathrm{GS} 1}$ \\
\hline Møkeren & $\mathrm{H}$ & $1942 / 3^{\mathrm{OM}}$ & & & & & & \\
\hline Nord-Elvåga & A & & $1942 / 3^{\mathrm{OM}}$ & & $1862^{\mathrm{GS} 1}$ & & & \\
\hline Nordre Åklangen (=Åbogen) & $\mathrm{H}$ & & & $1920^{\mathrm{Ol}}$ & & & & \\
\hline Nugguren (=Nuguren) & $\mathrm{H}$ & & $1942 / 3^{\mathrm{OM}}$ & & & & & \\
\hline Nøklevannet & A & & & & $1901 \mathrm{CB}$ & & & \\
\hline Orrevatnet & $\mathrm{R}$ & & & & $1880 \mathrm{~s}^{\mathrm{GS} 5}$ & & & \\
\hline Randsfjorden & $\mathrm{O}$ & $1880 \mathrm{~s}^{\mathrm{GS} 2}$ & & & & & & \\
\hline Rødenessjøen & $\varnothing$ & $1981^{\mathrm{NH}}$ & $1935^{\mathrm{SS}}$ & $1935^{\mathrm{SS}}$ & $2006^{\mathrm{KS}}$ & $1935^{\mathrm{SS}}$ & $2008^{\mathrm{IS} 2}$ & $1997^{\mathrm{IS} 2}$ \\
\hline Rømsjøen & $\varnothing$ & & $2003^{\mathrm{KS}}$ & & $2003^{\mathrm{KS}}$ & & & $2011^{\mathrm{IS} 2}$ \\
\hline Seimsjøen & $\mathrm{H}$ & & & $1942 / 3^{\mathrm{OM}}$ & $1942 / 3^{\mathrm{OM}}$ & & & \\
\hline Semsvannet & A & & & & $1942 / 3^{\mathrm{OM}}$ & & & \\
\hline Setten & A & $1982^{\mathrm{H} \varnothing 1}$ & $1981^{\mathrm{H} Ø 1}$ & $2005^{\mathrm{KS}}$ & $2001^{\mathrm{H} \varnothing}$ & $2005^{\mathrm{KS}}$ & & \\
\hline Skinnarbutjern & $\varnothing$ & & & $2012^{\mathrm{IS} 2}$ & & & & \\
\hline Skulerudvann & A & $2009^{\mathrm{IS} 2}$ & $2009^{S V}$ & $2009^{S V}$ & & & $1997 \mathrm{IS} 2$ & $2009^{I S 2}$ \\
\hline Sognsvann & A & & & & $1862^{\mathrm{GS} 1}$ & & & \\
\hline Stokkalandsvatnet & $\mathrm{R}$ & & $1942 / 3^{\mathrm{OM}}$ & $2012^{\mathrm{KKS}}$ & & & & \\
\hline Store Erte & $\varnothing$ & $1880 \mathrm{~s}{ }^{\mathrm{GS} 0}$ & & & & & & \\
\hline
\end{tabular}




\begin{tabular}{|c|c|c|c|c|c|c|c|c|c|}
\hline \multicolumn{2}{|l|}{ Lake } & County & 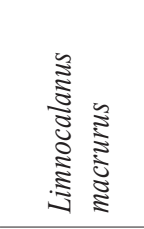 & $\stackrel{n}{\Sigma}$ & 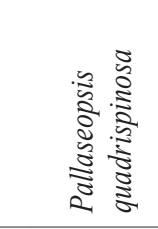 & 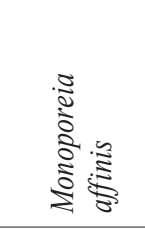 & 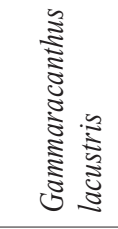 & 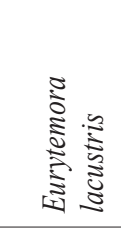 & 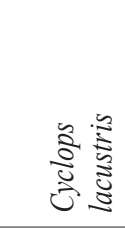 \\
\hline \multicolumn{2}{|c|}{ Store Le/Foxen } & $\varnothing$ & $1923^{\mathrm{ON}}$ & $1860 \mathrm{~s}^{\mathrm{SL}}$ & $1860 \mathrm{~s}^{\mathrm{SL}}$ & $1860 \mathrm{~s}^{\mathrm{SL}}$ & $1860 \mathrm{~s}^{\mathrm{SL}}$ & $1995^{\mathrm{IS} 1}$ & $1998^{\mathrm{IS} 2}$ \\
\hline \multicolumn{2}{|c|}{ Storsjøen (Odal) } & $\mathrm{H}$ & $1880 \mathrm{~s}^{\mathrm{GS} 2}$ & & $1863^{\mathrm{GS} 5}$ & $1942 / 3^{\mathrm{OM}}$ & & & \\
\hline \multicolumn{2}{|c|}{ Søndre Øyungen } & $\mathrm{H}$ & & $1994^{\mathrm{AL}}$ & & & & & \\
\hline \multicolumn{2}{|c|}{ Tannsjøen } & $\mathrm{H}$ & & $2001^{\mathrm{HM}}$ & & & & & \\
\hline \multicolumn{2}{|c|}{ Tyrifjorden } & B & $1862^{\mathrm{GS} 1}$ & & & & & & $1862^{\mathrm{GS}}$ \\
\hline \multicolumn{2}{|c|}{ Utgardsjøen } & $\mathrm{H}$ & $1942 / 3 \mathrm{OM}$ & & $1942 / 3^{\mathrm{OM}}$ & $1942 / 3 \mathrm{OM}$ & & & \\
\hline \multicolumn{2}{|c|}{ Vansjø } & $\varnothing$ & & $1968^{\mathrm{PA}}$ & & & & & \\
\hline \multicolumn{2}{|c|}{ Vestvannet(=Bjørnstadvann) } & $\varnothing$ & $1880 \mathrm{~s}$ GS0 & & & & & & \\
\hline \multicolumn{2}{|c|}{ Vingersjøen } & $\mathrm{H}$ & & & $1920^{02}$ & $1920^{02}$ & & & \\
\hline \multicolumn{2}{|c|}{ Øyeren } & $\mathrm{A}, \varnothing$ & $1942 / 3^{\mathrm{OM}}$ & $1935^{\mathrm{SS}}$ & $1935^{\mathrm{SS}}$ & & $1935^{\mathrm{SS}}$ & & $2015^{\mathrm{IS}}$ \\
\hline \multicolumn{2}{|c|}{ Øymarksjøen } & $\varnothing$ & $1981^{\mathrm{NH}}$ & $1981^{\mathrm{NH}}$ & $1997^{\mathrm{KS} 1}$ & $2002^{S V}$ & $2002^{\mathrm{SV}}$ & $1995^{\mathrm{IS} 1}$ & $1998^{\mathrm{IS} 2}$ \\
\hline $\mathrm{AL}$ & \multicolumn{3}{|c|}{ A. Linløkken (Bækken et al. 1999) } & IV & \multicolumn{5}{|c|}{ I. Spikkeland (Vøllestad 1983) } \\
\hline $\mathrm{CB}$ & \multicolumn{3}{|c|}{ C.W. Brøgger (Brøgger 1901) } & KKS & \multicolumn{5}{|c|}{ B. Kinsten, G. Kjellberg, I. Spikkeland (Spikkeland et al. 2012b) } \\
\hline ES & \multicolumn{3}{|c|}{ E. Snekvik (Løkke 1964) } & $\mathrm{KS}$ & \multicolumn{5}{|c|}{ R. Kasbo and I. Spikkeland (Spikkeland et al. 2012a) } \\
\hline GS? & \multicolumn{3}{|c|}{ G.O. Sars (Ekman 1922) } & KS1 & \multicolumn{5}{|c|}{ R. Kasbo and I. Spikkeland (Spikkeland 1997) } \\
\hline GS0 & \multicolumn{3}{|c|}{ G.O. Sars (Spikkeland et al. 2012a) } & LV & \multicolumn{5}{|c|}{ L.A. Vøllestad (Vøllestad 1983) } \\
\hline GS1 & \multicolumn{3}{|c|}{ G.O. Sars (Sars 1863a, 1863b) } & $\mathrm{NH}$ & \multicolumn{5}{|c|}{ J.P. Nilssen and G. Hardeng (Hardeng 1982) } \\
\hline GS2 & \multicolumn{3}{|c|}{ G.O. Sars (Sars 1903) } & $\mathrm{OM}$ & \multicolumn{5}{|c|}{ O. A. Mathisen (Mathisen 1953) } \\
\hline GS3 & \multicolumn{3}{|c|}{ G.O. Sars (Mathisen 1953) } & $\mathrm{ON}$ & \multicolumn{5}{|c|}{ O. Nybelin (Nybelin 1929) } \\
\hline GS4 & \multicolumn{3}{|c|}{ G.O Sars (Sømme 1936) } & $\mathrm{O} 1$ & O. Olstad (N & thisen 1953) & & & \\
\hline GS5 & G.O. Sars (Sars 1895 & & & $\mathrm{O} 2$ & O. Olstad (S & nme 1936) & & & \\
\hline GS6 & G.O. Sars (Sars 1867 & & & $\mathrm{PA}$ & P. Aass (Aas & 1969) & & & \\
\hline $\mathrm{HM}$ & H. Malmestrand (Ma & almestran & 2002) & SE & M. Eriksen a & d I. Spikkela & d (Spikkel & d et al. 201 & \\
\hline НØ & H. Ørjasæter (unpub & lished) & & SL & S. Lovén (Lc & rén 1863) & & & \\
\hline НØ1 & H. Ørjasæter (Spikke & eland et al & 2012a) & SS & S. Sømme (S & mme 1936) & & & \\
\hline JN & J.P. Nilssen (Spikkele & and et al. & 012a) & SS1 & I.D. Sømme & Sømme 1936 & & & \\
\hline IS & I. Spikkeland (unpub & lished) & & SV & I. Spikkelanc & and J.P. Vaal & (Spikkela & et al. 201 & \\
\hline IS1 & I. Spikkeland (Spikk & eland 199 & & WH & B. Walseng & Walseng \& H & sthagen 20 & & \\
\hline IS2 & I. Spikkeland (Spikk & eland et a & 2012a) & $\mathrm{TJ}$ & T. Jensen ( $\mathrm{S}$ & artau et al. 2 & & & \\
\hline
\end{tabular}

